\title{
The Construction of Supplier\&apos's Indicators of SPA Enterprise: the Perspective of International Supply Chain Environment
}

\author{
Ling Qiu \\ Fuzhou University of International Studies and Trade YuHuan Road, Souzhan New District, \\ Changle District, Fuzhou City, Fujian Province, China
}

Keywords: International Supply Chain Environ, SPA, The Indicator System.

\begin{abstract}
With the development of economic globalization and integration, under the background of international supply chain environment, SPA enterprises are constantly seeking efficient supply chain management methods in order to reduce supply chain cost, improve service capacity and improve the comprehensive strength of supply chain. This article is based on the basis of academic research, from the perspective of influence supplier selection and soft hard to build supplier index evaluation system, the analytic hierarchy process to determine the influence enterprise supplier selection through the network core index, provide the basis for enterprise supplier selection, deepen structural adjustment and transformation and upgrading for the enterprise to provide security.
\end{abstract}

\section{Introduction}

With the development of economic globalization, integration and informatization, enterprises urgently need new models to cope with market competition in order to adapt to the pressure of complex and changeable external environment. The enterprise management has realized the development from OEM (OEM (self-designed and manufactured) to OBM (free-brand manufacturing), and the Specialty retailer of Private label Apparel (SPA) comes into being under this background. SPA mode refers to that an enterprise owns its own brand, integrates product design, procurement and sales, and undertakes the function of connecting suppliers and consumers from the perspective of supply chain. In international SPA enterprise under the environment of supply chain in order to raise the overall strength of the supply chain, pay more attention to cost control on the supply chain, from product quality, delivery, transport costs, the price level, market sensitivity and ability to innovate, to seek effective method of procurement management, procurement management to reduce costs, improve the efficiency of enterprise management, to achieve the efficient allocation of resources in the international supply chain environment. As the pioneer of implementing SPA model, the garment and textile industry has established a set of efficient comprehensive supplier selection index system during the critical period of deepening structural adjustment and transformation and upgrading of the garment and textile industry, which can reduce the procurement cost of raw materials, improve the efficiency of supply chain and provide guarantee for the transformation and upgrading of the garment and textile industry. 


\section{The Basis}

A supply chain is a network of enterprises that take materials and process them into products and send them to consumers. The supply chain connects each intermediary enterprise, and the competition between each enterprise is mainly on the supply chain. The efficiency of the supply chain determines the efficiency of the enterprise, while the procurement management connects the enterprises before the supply chain and plays an important role in the whole process of the supply chain. Academics on the supplier's research mainly from the perspective of retail procurement suppliers, and the research from the perspective of the international supply chain SPA enterprise supplier selection research less, how to build up a high efficient SPA model of supplier selection index system will become our country clothing textile industry to join the international SPA competition is the key problem. The study on enterprise supplier selection in the international supply environment is not only important for SPA enterprises, but also important for circulation enterprises, manufacturing enterprises and service enterprises. At present, researches on supplier selection mainly focus on cost, transportation performance, delivery time, service quality, informatization degree, price level, production capacity, innovation ability and other aspects. This paper sorted out the following supplier selection index system through the research results and surveys of major scholars at home and abroad.

\section{The Construction of Supplier\&apos}

Based on the research foundation of relevant scholars, this paper considers the soft indicators such as organizational structure, enterprise innovation ability, market sensitivity, financial ability, organizational structure, management ability and informationization level which affect the supplier selection of SPA enterprises into the supplier evaluation system of SPA enterprises, and establishes a combination of rigid and soft indicators. The more perfect supplier index system of SPA enterprises under the international supply chain environment provides the basis for our SPA enterprises to join the international market.

Table 1. Evaluation Index System of SPA Enterprise Suppliers

\begin{tabular}{c|c|l}
\hline & Rule Layer & \multicolumn{1}{c}{ Index Layer } \\
\hline \multirow{4}{*}{$\begin{array}{c}\text { Rigid } \\
\text { Indicators }\end{array}$} & $\begin{array}{c}\text { Quality B1 } \\
\text { Capacity B2 }\end{array}$ & $\begin{array}{l}\text { Qualification RateC1,Return RateC2,Quality Improvement Cycle } \\
\text { C3, Quality Assurance System C4 }\end{array}$ \\
\cline { 2 - 3 } & $\begin{array}{l}\text { Flexible Production C5,Technical Level C6,Production } \\
\text { Efficiency C7,Equipment Capability C8,Production Scale C9 }\end{array}$ \\
\cline { 2 - 3 } & Price Level B3 & $\begin{array}{l}\text { Transportation Cost C10, product Cost C11, inventory Cost C12, } \\
\text { Shortage Cost C13 }\end{array}$ \\
\cline { 2 - 3 } & Supply Ability & $\begin{array}{l}\text { Delivery Cycle C14, Order Completion Rate C15, Delivery } \\
\text { Accuracy C16, Response Capacity C17, Cooperation Ability C18 }\end{array}$ \\
\hline \multirow{4}{*}{$\begin{array}{c}\text { Soft } \\
\text { Indicators }\end{array}$} & $\begin{array}{c}\text { Competitiveness } \\
\text { B5 }\end{array}$ & $\begin{array}{l}\text { Demand Feedback C19,After-sales Service C20,Market } \\
\text { Competition C21,Market Sensitivity C22 }\end{array}$ \\
\cline { 2 - 3 } & Level B6 & $\begin{array}{l}\text { Demand Feedback C19, After-sales Service C20, Market } \\
\text { Competition C21, Market Sensitivity C22 }\end{array}$ \\
\cline { 2 - 3 } & Ability B7 & $\begin{array}{l}\text { Design capability C27, Research ability C28,new technology } \\
\text { application C29,process integration capability C30 }\end{array}$ \\
\cline { 2 - 3 } & Sustainability & $\begin{array}{l}\text { Environmental Protection C31, Waste Discharge C32, Employee } \\
\text { Bealth C33, Work Environment C34 }\end{array}$ \\
\hline
\end{tabular}




\section{Construction of Supplier Evaluation System for SPA Enterprises Based on ANP}

\subsection{SPA Enterprise Supplier Evaluation Index Optimization}

This part designs questionnaires for the eight indicators of quality, production capacity, price level, supply capacity, market competitiveness, management level, innovation ability and sustainability constructed by the hard and soft indicators in Table 1, and analyses the importance of the secondary indicators under the eight indicators. By comparing the importance, we can optimize the criterion layer and the index layer. This research adopts the expert scoring method and invites experts to score 1-9 on the index level. A total of 130 questionnaires and 108 valid questionnaires are distributed.

Table 2. Description and Analysis of Evaluation Indicators

\begin{tabular}{|c|c|c|c|c|c|c|c|c|c|}
\hline & $\mathrm{B} 1$ & $\mathrm{~B} 2$ & B3 & B4 & B5 & B6 & B7 & B8 & 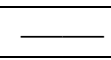 \\
\hline Number & 108 & 108 & 108 & 108 & 108 & 108 & 108 & 108 & 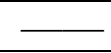 \\
\hline minimum & 7 & 7 & 7 & 5 & 5 & 5 & 7 & 3 & 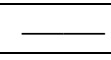 \\
\hline maximum & 9 & 9 & 9 & 9 & 9 & 8 & 9 & 6 & - \\
\hline mean & 7.12 & 8.03 & 8.36 & 6.67 & 6.03 & 5.66 & 7.93 & 4.51 & - \\
\hline \multirow[t]{3}{*}{ std.Deviation } & 0.854 & 0.834 & 0.821 & 0.804 & 0.932 & 1.123 & 0.879 & 1.171 & 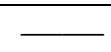 \\
\hline & \multicolumn{4}{|c|}{$\mathrm{B} 1$} & \multicolumn{5}{|c|}{ B2 } \\
\hline & $\mathrm{C} 1$ & $\mathrm{C} 2$ & C3 & $\mathrm{C} 4$ & $\mathrm{C} 5$ & C6 & C7 & $\mathrm{C} 8$ & C9 \\
\hline Number & 108 & 108 & 108 & 108 & 108 & 108 & 108 & 108 & 108 \\
\hline minimum & 6 & 5 & 4 & 5 & 5 & 4 & 6 & 6 & 5 \\
\hline maximum & 8 & 8 & 8 & 8 & 9 & 8 & 9 & 9 & 8 \\
\hline mean & 7.12 & 6.35 & 5.54 & 6.60 & 6.14 & 5.98 & 6.94 & 7.01 & 6.77 \\
\hline \multirow[t]{3}{*}{ std.Deviation } & 0.843 & 0.801 & 1.023 & 0.872 & 1.035 & 0.974 & 0.879 & 0.856 & 0.894 \\
\hline & \multicolumn{4}{|c|}{ B3 } & \multicolumn{5}{|c|}{ B4 } \\
\hline & C10 & C11 & C12 & C13 & $\mathrm{C} 14$ & $\mathrm{C} 15$ & C16 & C17 & C18 \\
\hline Number & 108 & 108 & 108 & 108 & 108 & 108 & 108 & 108 & 108 \\
\hline minimum & 6 & 7 & 7 & 7 & 6 & 4 & 5 & 4 & 4 \\
\hline maximum & 9 & 9 & 8 & 9 & 9 & 8 & 8 & 8 & 7 \\
\hline mean & 8.07 & 8.26 & 7.65 & 8.15 & 7.88 & 5.38 & 6.55 & 5.26 & 5.18 \\
\hline \multirow[t]{3}{*}{ std.Deviation } & 0.834 & 0.812 & 0.806 & 0.874 & 0.815 & 0.907 & 0.821 & 1.134 & 1.121 \\
\hline & \multicolumn{4}{|c|}{ B5 } & \multicolumn{4}{|c|}{ B6 } & \\
\hline & C19 & $\mathrm{C} 20$ & $\mathrm{C} 21$ & C22 & C23 & $\mathrm{C} 24$ & $\mathrm{C} 25$ & C26 & 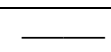 \\
\hline Number & 108 & 108 & 108 & 108 & 108 & 108 & 108 & 108 & - \\
\hline minimum & 5 & 5 & 4 & 4 & 3 & 4 & 4 & 4 & 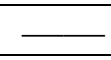 \\
\hline maximum & 8 & 8 & 8 & 8 & 8 & 8 & 9 & 8 & - \\
\hline mean & 6.90 & 7.23 & 5.13 & 5.01 & 4.94 & 6.03 & 6.67 & 4.65 & 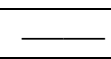 \\
\hline \multirow[t]{3}{*}{ std.Deviation } & 0.906 & 0.811 & 1.012 & 1.235 & 1.213 & 0.823 & 0.801 & 1.211 & - \\
\hline & \multicolumn{4}{|c|}{ B7 } & \multicolumn{4}{|c|}{ B8 } & \\
\hline & C27 & C28 & $\mathrm{C} 29$ & C30 & C31 & C32 & C33 & C34 & - \\
\hline Number & 108 & 108 & 108 & 108 & 108 & 108 & 108 & 108 & - \\
\hline minimum & 5 & 6 & 4 & 3 & 5 & 3 & 3 & 3 & $\bar{C}$ \\
\hline maximum & 9 & 8 & 7 & 7 & 7 & 6 & 5 & 5 & - \\
\hline mean & 7.92 & 7.55 & 5.76 & 4.53 & 5.85 & 4.32 & 4.12 & 3.84 & - \\
\hline std.Deviation & 0.815 & 0.836 & 0.934 & 1.125 & 0.821 & 1.211 & 1.113 & 1.256 & - \\
\hline
\end{tabular}


From the above results, we can see that the average score of criterion level indicators is B3 $>\mathrm{B} 7>$ $\mathrm{B} 2>\mathrm{B} 1>\mathrm{B} 4>\mathrm{B} 5>\mathrm{B} 6>\mathrm{B} 8$, and the standard deviation between B6 and B8 is large, indicating that the respondents have different views. Among them, the standard deviations of $\mathrm{C} 3, \mathrm{C} 5, \mathrm{C} 17$, C18, C21, C22, C23, C26, C30, C32, C33 and C34 are large and not representative, so they are eliminated. The optimized indexes are as follows:

Table 3. Evaluation Index System of SPA Enterprise Suppliers

\begin{tabular}{|c|c|c|}
\hline & Criterion Level & Index Level \\
\hline \multirow{4}{*}{$\begin{array}{l}\text { Rigid } \\
\text { Indicators }\end{array}$} & Quality B1 & $\begin{array}{l}\text { Qualification RateC1,Return RateC2, Quality Assurance } \\
\text { System C3 }\end{array}$ \\
\hline & Production Capacity B2 & $\begin{array}{l}\text { Technical Level C4,Production Efficiency C5,Equipment } \\
\text { Capability C6,Production Scale C7 }\end{array}$ \\
\hline & Price Level B3 & $\begin{array}{l}\text { Transportation cost C8,Product Cost C9,Inventory Cost } \\
\text { C10,Shortage CostC11 }\end{array}$ \\
\hline & Supply Ability B4 & $\begin{array}{l}\text { Delivery Cycle C12, Order Completion Rate C13, } \\
\text { Delivery Accuracy C14 }\end{array}$ \\
\hline \multirow{2}{*}{$\begin{array}{l}\text { Soft } \\
\text { Indicators }\end{array}$} & Competitiveness B5 & Demand Feedback C15,After-sales Service C16 \\
\hline & Innovation Ability B6 & $\begin{array}{l}\text { Design capability C17, Research ability C18,New } \\
\text { Technology ApplicationC19 }\end{array}$ \\
\hline
\end{tabular}

4.2. Establishment of Supplier Evaluation System for SPA Enterprises

Table 4. Index Weights at Indicator Level

\begin{tabular}{|c|c|c|c|c|c|}
\hline & Criterion Level & Indicators & Weighted & Limit & Sort \\
\hline \multirow{14}{*}{ 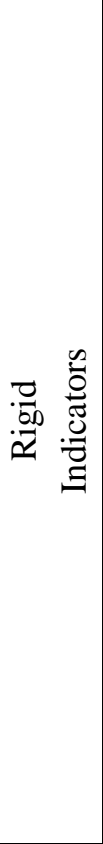 } & \multirow{3}{*}{ Quality B1 } & Qualification RateC1 & 0.42315 & 0.03008 & 9 \\
\hline & & Return RateC2 & 0.32561 & 0.01774 & 14 \\
\hline & & Quality Assurance System C3 & 0.25124 & 0.01856 & 13 \\
\hline & \multirow{4}{*}{$\begin{array}{l}\text { Production Capacity } \\
\text { B2 }\end{array}$} & Technical Level C4 & 0.15974 & 0.02263 & 11 \\
\hline & & Production Efficiency C5 & 0.30123 & 0.01675 & 15 \\
\hline & & Equipment Capability C6 & 0.31172 & 0.01212 & 16 \\
\hline & & Production Scale C7 & 0.22731 & 0.01147 & 17 \\
\hline & \multirow{4}{*}{ Price Level B3 } & Transportation cost C8 & 0.23791 & 0.12109 & 3 \\
\hline & & Product Cost C9 & 0.31234 & 0.21024 & 1 \\
\hline & & Inventory Cost C10 & 0.17863 & 0.08423 & 5 \\
\hline & & Shortage Cost C11 & 0.27112 & 0.16407 & 2 \\
\hline & \multirow{3}{*}{ Supply Ability B4 } & Delivery Cycle C12 & 0.38321 & 0.05635 & 6 \\
\hline & & Order Completion Rate C13 & 0.29497 & 0.02562 & 10 \\
\hline & & Delivery Accuracy C14 & 0.32182 & 0.03121 & 7 \\
\hline \multirow{5}{*}{ 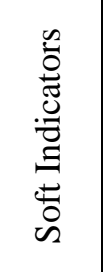 } & \multirow{2}{*}{ Competitiveness B5 } & Demand Feedback C15 & 0.41209 & 0.00865 & 19 \\
\hline & & After-sales Service C16 & 0.58791 & 0.02023 & 12 \\
\hline & \multirow{3}{*}{$\begin{array}{c}\text { Innovation Ability } \\
\text { B6 }\end{array}$} & Design Capability C17 & 0.38297 & 0.10798 & 4 \\
\hline & & Research Ability C18 & 0.32198 & 0.03011 & 8 \\
\hline & & New Technology Application C19 & 0.29505 & 0.01087 & 18 \\
\hline
\end{tabular}


In this part, according to the evaluation index system of SPA enterprise suppliers optimized, considering the relationship of mutual influence, mutual domination and interdependence between evaluation indexes, ANP is used to establish a reasonable network layer and calculate the total weight of each index.

The project invites an expert group composed of senior purchasing managers, relevant industry experts and university teachers to score, compare and check the consistency of the index system optimized, and calculate the weight of each index.

Firstly, the $\mathrm{W}$ judgment matrix between elements is established, and the weight vector is calculated according to the method of feature following to obtain the matrix; the column vector is the ranking vector of the influence degree of the middle elements on the middle elements; secondly, the consistency test index is established by checking whether the judgment matrix is reasonable; thirdly, the geometric mean formula is used to confirm the consistency test. Finally, the weights of all indicators are obtained from the limit matrix by calculating the weighted super matrix of the indicators. As shown in table 4.

\subsection{Analysis of Results}

From the results, the top ten rankings are: product cost $\mathrm{C} 9$, shortage cost $\mathrm{C} 11$, transportation cost C8, design capability C17, inventory cost C10, delivery cycle C12, delivery accuracy C14, Research Ability C18, qualification rate C1 and order completion rate C13. Among them, design ability C17 and research ability C18 rank fourth and eighth respectively in the soft indicators, and both indicators are innovation ability indicators, indicating that enterprise innovation ability has become an important indicator for supplier selection in SPA enterprises.

\section{Empirical Analysis}

A L enterprise is a SPA retail business model of its own brand in A province. It is a SPA enterprise that integrates raw material purchasing, planning, design, development, manufacturing and sales. SPA model is the primary goal to meet consumer demand. It can effectively Contact consumers and suppliers, connect the procurement, production and retail links of enterprises. By innovating supply methods and supply chain processes, it can achieve rapid response to the market. It can not only simplify the supply chain links, but also reduce the number of supply chains. It can also save enormous supply chain management costs, and provide reasonable support for enterprises to accelerate industrial upgrading, join the international supply chain and achieve long-term development.

The project team invites an expert team composed of senior purchasing managers, industry experts and university teachers to select eight major suppliers currently cooperating with L enterprises for evaluation in order to find several suppliers that have greater impact on $L$ enterprises. The steps are as follows:

Firstly, the evaluation index is determined and the attribute of the index is defined. According to the known results of previous ANP operations, the top ten indicators are selected to construct the evaluation matrix. Indicator weights are:

$\mathrm{W}=(0.21024,0.16407,0.12109,0.10798,0.08423,0.08423,0.03121,0.03011,0.03008$, 0.02562 )。

Second, experts scored. Quantitative data on relevant indicators of eight suppliers and industries are provided to the expert group, including product cost C9, shortage cost C11, transportation cost C8, inventory cost C10, delivery cycle C12, delivery accuracy C14, qualification rate C1 and order completion rate C13. Based on qualitative and quantitative indicators, the expert group scored 8 suppliers of L enterprise 1-9. The weights of three kinds of experts are: Senior Purchasing Manager 
$=0.4$, industry expert $=0.3$ and university professor $=0.3$. The ratings of eight suppliers are as follows. Due to the limited space, only the top four supplier ratings are listed.

Table 5. Ranks the Top Four Vendors to Be Selected

\begin{tabular}{|c|c|c|c|c|c|c|c|c|}
\hline \multirow[b]{2}{*}{ Indicators } & \multicolumn{4}{|c|}{$\mathrm{Z} 1$} & \multicolumn{4}{|c|}{ Z3 } \\
\hline & Manager & $\begin{array}{l}\text { Industry } \\
\text { Experts }\end{array}$ & $\begin{array}{l}\text { Profe } \\
\text { ssor }\end{array}$ & Score & Manager & $\begin{array}{l}\text { Industry } \\
\text { Experts }\end{array}$ & $\begin{array}{l}\text { Profes } \\
\text { sor }\end{array}$ & Score \\
\hline Product Cost & 9 & 8 & 8 & 8.4 & 8 & 7 & 7 & 7.4 \\
\hline Shortage Cost & 8 & 7 & 8 & 7.7 & 8 & 7 & 8 & 7.7 \\
\hline $\begin{array}{c}\text { Transportation } \\
\text { Cost }\end{array}$ & 8 & 8 & 7 & 7.7 & 7 & 8 & 7 & 7.3 \\
\hline Design Ability & 7 & 8 & 8 & 7.6 & 8 & 8 & 7 & 7.7 \\
\hline Inventory Cost & 8 & 7 & 8 & 7.7 & 8 & 7 & 7 & 7.4 \\
\hline Delivery Cycle & 8 & 8 & 7 & 7.7 & 7 & 8 & 7 & 7.3 \\
\hline Delivery Accuracy & 7 & 8 & 8 & 7.6 & 7 & 7 & 8 & 7.3 \\
\hline Research Ability & 8 & 8 & 7 & 7.7 & 8 & 8 & 9 & 8.3 \\
\hline Qualification Rate & 7 & 8 & 7 & 7.3 & 7 & 7 & 8 & 7.3 \\
\hline $\begin{array}{c}\text { Order Completion } \\
\text { Rate }\end{array}$ & 8 & 7 & 7 & 7.4 & 8 & 7 & 6 & 7.1 \\
\hline \multirow[b]{2}{*}{ Indicators } & \multicolumn{4}{|c|}{ Z7 } & \multicolumn{4}{|c|}{ Z5 } \\
\hline & Manager & $\begin{array}{l}\text { Industry } \\
\text { Experts }\end{array}$ & $\begin{array}{l}\text { Profe } \\
\text { ssor }\end{array}$ & Score & Manager & $\begin{array}{l}\text { Industry } \\
\text { Experts }\end{array}$ & $\begin{array}{l}\text { Profes } \\
\text { sor }\end{array}$ & Score \\
\hline Product Cost & 8 & 7 & 7 & 7.4 & 7 & 7 & 6 & 7 \\
\hline Shortage Cost & 7 & 8 & 7 & 7.3 & 8 & 7 & 7 & 7.4 \\
\hline $\begin{array}{c}\text { Transportation } \\
\text { Cost }\end{array}$ & 8 & 7 & 7 & 7.7 & 7 & 6 & 6 & 6.4 \\
\hline Design Ability & 7 & 6 & 6 & 6.4 & 7 & 7 & 7 & 7 \\
\hline Inventory Cost & 7 & 7 & 7 & 7 & 7 & 7 & 6 & 6.7 \\
\hline Delivery Cycle & 7 & 7 & 6 & 6.7 & 8 & 7 & 7 & 7 \\
\hline Delivery Accuracy & 7 & 7 & 7 & 7 & 7 & 7 & 8 & 7.3 \\
\hline Research Ability & 8 & 8 & 8 & 8 & 7 & 7 & 6 & 6.7 \\
\hline Qualification Rate & 7 & 7 & 7 & 7 & 6 & 7 & 7 & 6.6 \\
\hline $\begin{array}{c}\text { Order Completion } \\
\text { Rate }\end{array}$ & 7 & 6 & 6 & 6.4 & 7 & 7 & 6 & 6.7 \\
\hline Indicators & \multicolumn{8}{|l|}{...... } \\
\hline
\end{tabular}

Thirdly, the evaluation matrix of pairwise comparison is constructed according to the aforementioned method.

Finally, the conclusion is drawn by comprehensive calculation. The importance coefficients of eight suppliers are $Q=(0.20134,0.09013,0.17091,0.08661,0.13142,0.09013,0.15022,0.06756)$, respectively. The conclusion of supplier ranking is $\mathrm{Z} 1>\mathrm{Z3}>\mathrm{Z7}>\mathrm{Z} 5>\mathrm{Z6}>\mathrm{Z} 2>\mathrm{Z} 4>\mathrm{Z} 8$.

In summary, according to the core indicators selected by the above-mentioned suppliers, $L$ enterprises should focus on the hard indicators with price level as the core and the soft indicators 
with innovation ability as the new breakthrough. In addition to focusing on sorting out the strongest Z1 suppliers, L enterprises should pay special attention to Z3 enterprises with high evaluation of soft innovation ability in design ability and research ability, do a good job in supplier ranking, set up corresponding incentive mechanism, stimulate supplier participation, improve supply chain efficiency, and serve SPA enterprises. Joining the international supply chain, deepening structural adjustment, and realizing transformation and upgrading to provide security.

\section{Acknowledgement}

This paper was supported by Fujian Social Science Planning Youth Project 2016. The project is No. FJ2016C149. The topic of this project is named with"Research on the innovative development of garment SPA industry in fujian province under the international supply chain environment”.

\section{References}

[1]Jinhonghong, Yeyi.The index system of supplier selection under SPA mode is constructed [J]. China Market, 2015 (29): 172-174.

[2]Xu Kaizhao.Q Enterprise Supplier Selection Research [M]. Shanghai: Donghua University, 2015.

[3] Liu Cheng, Lu Yujuan. Supplier Selection in Fuzzy Environment [J]. Systems Engineering, 2014, (4): 104-108. 